\title{
POLA KONSUMSI MAKANAN PENDAMPING ASI (MP- ASI) PADA BAYI USIA 12-24 BULAN (CONSUMPTION PATTERN OF COMPLEMENTARY FOOD IN INFANTS AGES 12-24 MONTHS)
}

\author{
Rostika$^{1}$, Ellis Endang Nikmawati ${ }^{1}$, Cica Yulia ${ }^{1}$ \\ Program Studi Pendidikan Tata Boga, Departemen Pendidikan Kesejahteraan \\ Keluarga, Fakultas Teknologi dan Kejuruan, Universitas Pendidikan Indonesia \\ tikarostika05@gmail.com
}

\begin{abstract}
Abstrak: Beberapa masalah yang berkaitan dengan pola konsumsi Makanan Pendamping ASI (MPASI) pada bayi usia 12-24 bulan yaitu memiliki nafsu makan rendah, suka memilih jenis makanan tertentu, dan tidak ingin makan dalam jumlah banyak sehingga akan berpengaruh terhadap status gizi bayi. Tujuan dalam penelitian ini adalah memperoleh gambaran pola konsumsi MP-ASI yang berkaitan dengan jenis MP-ASI, frekuensi konsumsi MP-ASI dan tingkat kecukupan gizi MP-ASI. Metode penelitian ini menggunakan metode deskriptif dengan desain cross sectional. Teknik pengambilan sampel yaitu simple random sampling dengan jumlah responden 60 orang. Instrumen berupa kuesioner penelitian, semiquantitative food frequency questionnaire dan recall 2x24 jam. Hasil penelitian menunjukkan bahwa sebagian besar $(76,7 \%)$ bayi usia $12-24$ bulan mengonsumsi jenis makanan sesuai dengan anjuran Kemenkes 2014 yaitu makanan padat berupa nasi dan lauk pauk seperti makanan keluarga. Frekuensi makan pada bayi usia 12-24 bulan di Kelurahan Isola lebih dari setengahnya (65\%) bayi mengonsumsi makanan utama sebanyak 3-4 kali/hari dan 71,6\% mengonsumsi makanan selingan sebanyak 1-2 kali/hari. Kontribusi zat gizi MP-ASI terhadap pemenuhan AKG diantaranya energi sebesar $58,9 \%$, zat gizi protein sebesar $80,2 \%$. zat gizi lemak sebanyak 43,5\%, kontribusi karbohidrat sebesar 69,1\%, kecukupan mineral kalsium sebanyak 23,4\%, fosfor sebesar 35,7\%, zat besi memenuhi 66,4\%, vitamin A sebanyak 65,8\% dan vitamin C sebesar $58,7 \%$. Berdasarkan hasil penelitian ini diharapkan masyarakat dapat memberikan konsumsi MP-ASI kepada bayi usia 12-24 bulan dengan lebih baik lagi.
\end{abstract}

Kata kunci : Konsumsi, MP-ASI, Bayi 12-24 Bulan

\section{PENDAHULUAN}

$\begin{array}{ll}\text { Usia } & 0-24 \text { bulan merupakan } \\ \text { masa } & \text { pertumbuhan }\end{array}$
perkembangan yang pesat, sehingga sering diistilahkan sebagai periode emas sekaligus periode kritis. Untuk menunjang masa pertumbuhan dan perkembangan bayi usia 6-24 bulan dibutuhkan asupan gizi pendukung ASI yaitu dengan memberikan makanan pendamping ASI (MPASI). "Makanan Pendamping Air Susu Ibu (MP-ASI) adalah makanan dan minuman yang diberikan pada bayi atau anak usia 6-24 bulan yang mengandung zat gizi guna memenuhi kebutuhan gizi selain ASI" (Mufida, 2015, hlm.3). Fungsi Makanan Pendamping ASI antara lain untuk mengenalkan jenis makanan baru, memenuhi kebutuhan gizi yang tidak lagi dapat dipenuhi oleh ASI, membentuk daya pertahanan tubuh dan perkembangan sistem imunologis atau kekebalan tubuh terhadap makanan maupun minuman.

Kebiasaan konsumsi makanan keluarga dapat menjadikan bayi memiliki pola makan yang sama 
ketika dewasa. Menurut Allen dan Lynn (2010, hlm.107) permasalahan makan anak usia 12-24 bulan yaitu nafsu makannya lebih rendah, makan siang adalah waktu makan yang paling disukai, kadang-kadang hanya ingin makan makanan tertentu saja, suka memilih jenis makanan tertentu, tidak ingin makan dalam jumlah banyak, terkadang membiarkan makanan di dalam mulutnya tanpa mengunyah, hal ini dapat disebabkan anak tidak ingin makan lebih banyak lagi.

Makanan Pendamping ASI (MPASI) yang diberikan pada bayi berbeda dengan makanan pada umumnya. Organ pencernaan yang masih rentan dan kemampuan metabolisme yang belum sempurna menyebabkan makanan yang diberikan harus selalu diperhatikan dan memiliki syarat tertentu. Berdasarkan Kemenkes (2014, hlm.31) syarat MP-ASI diantaranya adalah padat energi, protein dan zat gizi, tidak berbumbu tajam, tidak menggunakan gula dan garam tambahan, penyedap rasa, pewarna dan pengawet secukupnya, mudah ditelan dan disukai anak, tersedia lokal dan harga terjangkau.

Jenis Makanan Pendamping ASI (MP-ASI) yang tepat dan diberikan sesuai dengan tahapan usia anak berdasarkan Kemenkes (2014, hlm.76) adalah sebagai berikut.

Tabel 1. Jenis Makanan Pendamping ASI

\begin{tabular}{|l|c|c|c|c|}
\hline \multirow{2}{*}{$\begin{array}{c}\text { Usia } \\
\text { (bulan }\end{array}$} & \multicolumn{4}{|c|}{ Pola Pemberian MP-ASI } \\
\cline { 3 - 5 } & AS & \multicolumn{3}{|c|}{ MP-ASI } \\
\cline { 3 - 5 } & & $\begin{array}{c}\text { Makana } \\
\text { n Lumat }\end{array}$ & $\begin{array}{c}\text { Makana } \\
\text { n Lunak }\end{array}$ & $\begin{array}{c}\text { Makana } \\
\text { n Padat }\end{array}$ \\
\hline $0-6$ & & & & \\
\hline $6-9$ & & & & \\
\hline $9-12$ & & & & \\
\hline $12-24$ & & & & \\
\hline
\end{tabular}

Sumber : Kemenkes (2014, hlm.76)
Berdasarkan tabel di atas bahwa pada usia 0-6 bulan anak dianjurkan hanya diberikan ASI. Anak usia 6-9 bulan secara bertahap diberikan makanan lumat seperti bubur susu, bubur sum-sum, pisang saring dan lainnya yang bersifat halus. Kemudian pada usia 9-12 bulan sudah dapat mengonsumsi makanan lunak seperi bubur nasi, nasi tim dan sebagainya. Sedangkan pada usia 12-24 bulan sudah dapat diperkenalkan makanan padat seperti lontong, nasi dan beragam lauk pauk namun dengan beberapa syarat seperti tidak boleh mengandung banyak garam dan gula, penyedap rasa maupun bumbu yang berbau tajam.

Frekuensi pemberian MP-ASI yang dianjurkan untuk anak usia 12-24 bulan berdasarkan Kemenkes (2014, hlm.76) adalah diberikan makanan utama 3-4 kali sehari dan makanan selingan 1-2 kali sehari. Kandungan gizi yang diperoleh dari MP-ASI berkontribusi terhadap pemenuhan Angka Kecukupan Gizi (AKG) yang dianjurkan (per orang per hari) untuk orang Indonesia. AKG untuk bayi usia 12-24 bulan berdasarkan Kemenkes 2014 yaitu energi $1125 \mathrm{kkal}$, protein $26 \mathrm{~g}$, lemak $44 \mathrm{~g}$, karbohidrat $155 \mathrm{~g}$, kalsium $650 \mathrm{mg}$, fosfor $500 \mathrm{mg}$, besi 8 $\mathrm{mg}$, vitamin A $400 \mathrm{RE}$ dan vitamin $\mathrm{C}$ $40 \mathrm{mg}$.

Berdasarkan pemaparan di atas, peneliti tertarik untuk melakukan penelitian mengenai pola konsumsi MP-ASI berdasarkan jenis, frekuensi dan tingkat kecukupan gizi bayi usia 12-24 bulan yang berlokasi di wilayah Kelurahan Isola, Kecamatan Sukasari, Kota Bandung dimana sasarannya pada ibu yang memiliki bayi rentang usia 12-24 bulan. 


\section{METODE PENELITIAN}

Penelitian ini menggunakan metode penelitian deskriptif dengan desain cross sectional (potong lintang) yaitu dengan melakukan pengamatan atau pengukuran pada saat bersamaan atau sekali waktu kepada responden penelitian. Lokasi penelitian di Kelurahan Isola, Kecamatan Sukasari, Kota Bandung. Jumlah posyandu yang terdapat di kelurahan adalah sebanyak 12 posyandu dengan jumlah populasi bayi usia 12-24 bulan sebanyak 147 orang. Teknik pengambilan sampel yang digunakan adalah Simple Random Sampling sejumlah 60 responden.

Teknik pengumpulan data menggunakan food recall 2x24 jam, semiquantitative food frequency questionnaire dan kuesioner yang dilakukan melalui wawancara kepada responden. Metode food recall 2x24 jam digunakan untuk mengetahui gambaran konsumsi dan tingkat kecukupan gizi MP-ASI bayi usia 1224 bulan dari makanan yang dikonsumsi dengan membandingkan berdasarkan AKG (Angka Kecukupan Gizi) untuk orang Indonesia. Metode Semiquantitative food frequency questionnaire (FFQ) digunakan untuk melihat seberapa sering suatu jenis bahan makanan diberikan kepada bayi usia 12-24 bulan, sehingga dapat terlihat frekuensi konsumsi suatu bahan makanan dalam MP-ASI. Adapun kuesioner penelitian digunakan untuk menggali informasi lebih mendalam mengenai pemberian MP-ASI berdasarkan jenis bahan makanan, syarat pemberian MP-ASI dan frekuensi pemberian makanan utama dan makanan selingan pada bayi usia 12-24 bulan.

Data konsumsi pangan diperoleh dari food recall $2 \times 24$ jam kemudian dikonversikan ke dalam satuan energi dan zat gizi dengan menggunakan Daftar Komposisi Bahan Makanan (DKBM). Konversi dapat dihitung menggunakan rumus menurut Perdana dan Hardinsyah (2013, hlm.41) sebagai berikut :

$$
\mathrm{KGij}=\frac{B j}{100} x G i j x \frac{B D D j}{100}
$$

Keterangan:

$$
\begin{aligned}
\text { Kgij }= & \text { Kandungan zat gizi-i } \\
& \text { dalam bahan makanan- } \mathrm{j} \\
\mathrm{Bj}= & \text { Berat makanan }-\mathrm{j} \text { yang } \\
& \text { dikonsumsi }(\mathrm{g}) \\
\mathrm{Gij}= & \text { Kandungan zat gizi } \\
& \text { dalam 100 gram BDD } \\
& \text { bahan makanan- } \mathrm{j} \\
\mathrm{BDDj}= & \text { Bagian bahan makanan-j } \\
& \text { yang dapat dimakan } \\
& (\% \text { BDD })
\end{aligned}
$$

Penilaian tingkat konsumsi gizi dilakukan dengan membandingkan antara konsumsi gizi responden dengan kecukupan gizi yng dinyatakan dalam persen. Secara umum tingkat konsumsi gizi dirumuskan sebagai berikut Perdana dan Hardinsyah (2013, hlm.42):

$$
\mathrm{TKG}(\%)=\frac{\text { Asupan } \text { zat gizi }}{A K G i} \times 100 \%
$$

Keterangan:

$\mathrm{TKG}=$ Tingkat konsumsi zat gizi $(\%)$

$\mathrm{AKGi}=$ Kecukupan zat gizi i yang dianjurkan

Data hasil wawancara berbentuk recall $2 \times 24$ jam agar lebih mudah dipahami penulis melakukan analisis yang bersifat deskriptif dengan 
menganalisa dan menginterpretasikan data secara utuh dari hasil wawancara.

Penafsiran data pada frekuensi makanan dan kuesioner penelitian melakukan tahapan persentase data. Rumus yang digunakan untuk menghitung persentase ini mengacu pada rumus yang dikemukakan oleh Sudjana (2010, hlm. 69) yaitu:

$$
\mathrm{P}=\frac{f}{n} \times 100 \%
$$

Keterangan :

P : Persentase yang dicari

f : frekuensi jawaban responden

n : jumlah responden

100 : bilangan tetap

Setelah penafsiran data, untuk menghasilkan data yang lebih jelas maka jawaban responden dilakukan penafsiran berdasarkan kriteria penafsiran yang dikemukakan oleh Riduwan (2010, hlm. 184) yaitu:

$100 \%=$ Seluruhnya

$76 \%-99 \%=$ Sebagian besar

$51 \%-75 \%=$ Lebih dari setengahnya

$50 \%=$ Setengahnya

$26 \%-49 \%=$ Kurang dari setengahnya

$1 \%-25 \%=$ Sebagian kecil

$0 \%=$ Tidak seorangpun.

\section{HASIL DAN PEMBAHASAN}

\section{Jenis Konsumsi Makanan Pendamping ASI (MP-ASI)}

Jenis makanan pendamping ASI (MP-ASI) dalam penelitian ini adalah makanan berdasarkan tahapan usia bayi yaitu makanan lumat, makanan lunak dan makanan padat beserta jenis makanan dan minuman yang biasa dikonsumsi bayi seperti makanan pokok, lauk hewani, lauk nabati, sayuran, buah-buahan, makanan selingan dan minuman.

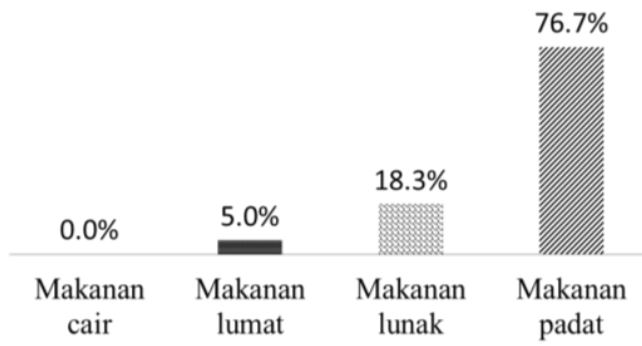

Gambar 1. Jenis Konsumsi MP-ASI

Makanan yang diberikan pada bayi usia 12-24 bulan di Kelurahan Isola sebagian besar yaitu sekitar $76,7 \%$ sudah mengonsumsi makanan dalam bentuk makanan padat seperti nasi dan lauk pauk seperti makanan keluarga, hal ini sudah sesuai dengan anjuran Kemenkes (2014, hlm.76) bahwa usia 12-24 bulan bayi harus sudah dikenalkan dengan makanan berbentuk padat dengan tetap memperhatikan syarat MP-ASI dan kecukupan konsumsi zat gizi (Gambar $1)$.

Sebagian besar $(73,3 \%)$ bayi usia 12-24 bulan di Kelurahan Isola mengonsumsi nasi sebagai makanan pokok. Nasi merupakan jenis serelia yang paling banyak dikonsumsi oleh masyarakat Indonesia sehingga konsumsi nasi pada bayi usia 12-24 bulan ketika masuk pada tahapan makanan padat akan lebih banyak dikonsumsi sebagai makanan pokok dari pada jenis makanan lainnya.

Kurang dari setengahnya (45\%) bayi usia 12-24 bulan mengonsumsi telur sebagai lauk hewani. Berdasarkan Kemenkes (2010, hlm.1) bahwa telur merupakan bahan pangan padat gizi dan mempunyai kandungan gizi yang lengkap dimana telur mengandung hampir semua zat gizi yang diperlukan tubuh kecuali vitamin C. Berdasarkan hal tersebut maka konsumsi telur sebagai lauk hewani dapat dipilih sebagai pemenuhan zat gizi protein dalam tubuh bayi. 
Sebagian besar bayi usia 12-24 bulan yaitu $86,7 \%$ mengonsumsi olahan sosis, bakso dan nugget sebagai produk olahan cepat saji. Mengonsumsi olahan cepat saji seperti sosis, bakso dan nugget dan lainnya harus dilakukan dengan bijak. Menurut Palandeng dkk (2016, hlm.20) karakteristik sosis yang baik adalah teksturnya kenyal, tidak mengandung bahan pengawet, bebas bahan kimia berbahaya dan tidak mengandung pewarna sintetis yang dapat membahayakan jika dikonsumsi. Begitpun halnya dengan olahan daging lainnya seperti abon, dendeng, kornet dan daging asap harus diperhatikan kualitas dan keamanan bahan pangan yang digunakannya.

Sebagian besar $(88,3 \%)$ bayi usia 12-24 bulan lebih sering mengonsumsi tahu sebagai lauk nabati. Konsumsi tahu lebih banyak dikonsumsi karena tahu memiliki tekstur lebih lembut dari pada jenis lauk nabati lainnya sehingga proses mengunyah pada bayi menjadi lebih mudah. Menurut Shurtleff dan Aoyagi (dalam Wahyuningsih, 2017, hlm.4) tahu memiliki daya cerna $95 \%$ sehingga tahu dapat dikonsumsi dengan aman oleh semua golongan umur dari bayi hingga dewasa.

Lebih dari setengahnya $(51,7 \%)$ bayi usia 12-24 bulan mengonsumsi sayuran wortel. Jenis sayuran yang dikonsumsi oleh anak sebaiknya menghindari sayuran dengan kandungan serat tinggi, sejalan dengan pendapat Mufida (2015, hlm.5) bahwa syarat MP-ASI "hendaknya bersifat padat gizi, makanan yang memiliki banyak kandungan serat dan bahan makanan lain yang sulit dicerna diberikan seminimal mungkin, sebab serat yang terlalu banyak jumlahnya akan mengganggu proses pencernaan dan penyerapan zat-zat gizi". Sebanyak $41,7 \%$ bayi usia $12-24$ bulan paling sering mengonsumsi pisang daripada buah lainnya. Mengonsumsi buah-buahan secara teratur dapat membantu kesehatan tubuh bayi karena buah-buahan banyak mengandung vitamin dan mineral yang diperlukan bayi.

Lebih dari setengahnya $(71,7 \%)$ bayi usia 12-24 bulan mengonsumsi jenis biskuit, kue bolu dan wafer sebagai pemenuhan kebutuhan makanan selingan. Berdasarkan Unicef (2012, hlm.31) bahwa makanan selingan yang bergizi untuk bayi usia 12-24 bulan diantaranya buah-buahan seperti mangga, pisang, alpukat, atau buah-buahan dan sayuran lain, lalu bayi jangan diberikan makanan yang terlalu manis seperti biskuit manis atau makanan manis lainnya.

Sebanyak $41,7 \%$ bayi usia $12-24$ bulan mengonsumsi susu kotak dan sebagian kecil (3,3\%) lebih sering mengonsumsi minuman kemasan seperti merk ale-ale, okky jelly drink dan sebagainya. Minuman kemasan tidak cocok dikonsumsi oleh bayi usia 12-24 bulan karena mengandung pemanis buatan seperti siklamat dan aspartam serta bahan kimia lainnya yang berbahaya bagi kesehatan bayi. Menurut Martindale (dalam Sumartini, 2015, hlm.122) bahwa penggunaan aspartam pada anak-anak akan memicu timbulnya kanker otak, dampaknya akan terjadi keluhan seperti sakit kepala, gejala perilaku, kejang dan hipersensitivitas pada anak. Berdasarkan hal tersebut sebaiknya konsumsi minuman kemasan yang mengandung bahan pemanis buatan dihindari pada anak.

\section{Frekuensi Konsumsi Makanan Pendamping ASI (MP-ASI)}

Frekuensi konsumsi Makanan Pendamping ASI (MP-ASI) pada bayi usia 12-24 bulan meliputi frekuensi 
konsumsi makanan utama dan makanan selingan.

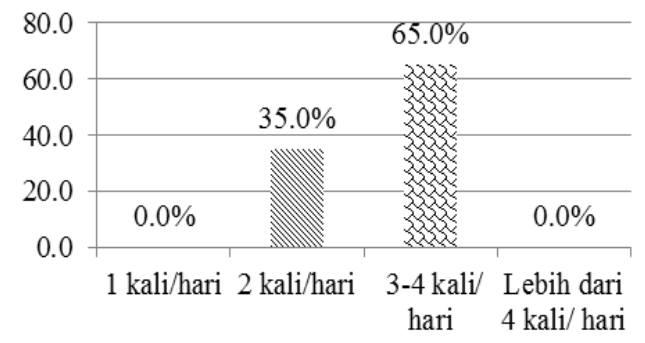

Gambar 2. Frekuensi Konsumsi Makanan Utama Bayi

Frekuensi konsumsi makanan utama bayi usia 12-24 bulan di Kelurahan Isola lebih dari setengahnya $(65 \%)$ mengonsumsi makanan utama seperti nasi dan lauk pauk dengan frekuensi 3-4 kali/hari, hal ini sudah sesuai dengan anjuran Kemenkes (2014, hlm.76) bahwa frekuensi pemberian MP-ASI yang dianjurkan untuk anak usia 12-24 bulan adalah sebanyak 3-4 kali sehari. Kurang dari setengahnya (35\%) bayi mengonsumsi makanan utama dengan frekuensi 2 kali/hari dan tidak ada seorangpun bayi yang mengonsumsi makanan utama dalam frekuensi $1 \mathrm{kali} / \mathrm{hari}$ dan lebih dari 4 kali/hari (Gambar 2).

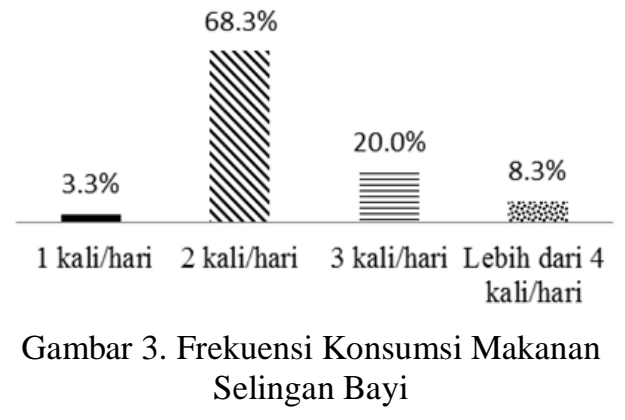

Frekuensi konsumsi makanan selingan seperti kue, biskuit, jus dan lainnya pada bayi usia 12-24 bulan lebih dari setengahnya $(68,3 \%)$ bayi mengonsumsi makanan selingan dengan frekuensi $2 \mathrm{kali} / \mathrm{hari}$, sebagian kecil mengonsumsi dengan frekuensi 1 kali/hari (3,3\%), 3 kali/hari (20\%) dan lebih dari 4 kali $(8,3 \%)$ (Gambar 3). Berdasarkan hasil persentase di atas bahwa lebih dari setengahnya bayi usia 12-24 bulan di Kelurahan Isola sudah mengonsumsi makanan selingan sesuai anjuran Kemenkes 2014 yaitu 1-2 kali sehari.

Frekuensi konsumsi jenis makanan pada bayi usia 12-24 bulan yaitu berdasarkan frekuensi konsumsi makanan pokok, lauk hewani, lauk nabati, sayuran, buah-buahan, makanan selingan dan minuman. Sebanyak $61,7 \%$ bayi usia $12-24$ bulan di Kelurahan Isola mengonsumsi nasi dengan frekuensi $>1 \mathrm{x} /$ hari dan rata-rata konsumsinya yaitu 98,4 gram, lalu sebanyak 58,3\% bayi usia 12-24 bulan tidak pernah mengonsumsi mie sebagai variasi bahan makanan pokok. Berdasarkan Survei Konsumsi Makanan Individu tahun 2014 menunjukkan rata-rata konsumsi serealia penduduk Indonesia didominasi oleh beras dan olahannya.

Konsumsi telur sebagai variasi lauk hewani dikonsumsi oleh $46,7 \%$ bayi usia 12-24 bulan dengan frekuensi 3x/minggu rata-rata konsumsinya sebanyak 49,1 gram. Hal ini sejalan dengan hasil penelitian Nurhayati (2000, hlm.58) bahwa jenis lauk pauk sumber protein hewani yang dikonsumsi dua kali atau lebih dalam seminggu untuk golongan usia 13-24 bulan adalah telur dengan rata-rata konsumsi 13,53+ 12,81 per hari. Sedangkan bahan makanan seperti dendeng, abon, daging asap dan kornet sebagian besar tidak pernah 
dikonsumsi oleh bayi usia 12-24 bulan.

$\begin{array}{lrr}\text { Bayi usia } & 12-24 & \text { bulan di } \\ \text { Kelurahan Isola } & \text { lebih } & \text { sering } \\ \text { mengonsumsi } & \text { tahu } & \text { sebagai }\end{array}$
pemenuhan zat gizi lauk nabati, hal ini terlihat dari persentase bayi yaitu $38,3 \%$ mengonsumsi tahu dengan frekuensi 1x/hari dan rata-rata konsumsinya 39,1 gram. Menurut penelitian Nurhayati (2000, hlm.57) konsumsi tahu pada anak usia 13-24 bulan yaitu dengan rata-rata frekuensi $0,51 \pm 0,32$ per hari dan rata-rata konsumsinya yaitu $22,48 \pm 13,23$ per hari. Sedangkan bahan lauk nabati seperti kacang merah dan kacang tanah dikonsumsi dengan frekuensi cukup jarang yaitu $1 \mathrm{x} /$ bulan masingmasing $10,0 \%$ dan $6,7 \%$ bayi. Sayuran yang paling sering dikonsumsi adalah bayam dan wortel. Sayuran bayam dikonsumsi oleh $20,0 \%$ bayi usia 12 24 bulan dengan frekuensi konsumsi $1 x$ /hari dan rata-rata konsumsinya sebanyak 6,3 gram dan sayuran wortel dikonsumsi oleh sebagian besar $(73,3 \%)$ dengan frekuensi $3 x /$ minggu dan rata-rata konsumsinya yaitu 10 gram. Hal ini sejalan dengan penelitian Nurhayati (2000, hlm. 58) bahwa sayuran yang paling banyak dikonsumsi oleh anak usia 13-24 bulan adalah worteldan bayam, dimana frekuensi konsumsi wortel sebanyak $0.26 \pm 0.18 \mathrm{kali} / \mathrm{hari}$ atau sekitar $1.95 \mathrm{kali} / \mathrm{minggu}$.

Menurut penelitian Nurhayati (2000, hlm.59) jenis buah yang sering dikonsumsi oleh bayi usia 13-24 bulan adalah pisang dan pepaya dengan frekuensi berturut-turut yaitu $0.19 \pm$ $0.17 \mathrm{kali} / \mathrm{hari}$ dan $0.41 \pm 0.31$ kali/hari. Berdasarkan penelitian yang sudah dilakukan di Kelurahan Isola bahwa buah yang paling banyak dikonsumsi adalh pisang dan jeruk. Buah pisang dikonsumsi oleh 58,3\% bayi usia 12-24 bulan dengan frekuensi $3 x /$ minggu dan rata-rata konsumsinya yaitu 53,6 gram, lalu konsumsi jeruk dengan frekuensi $3 \mathrm{x} /$ minggu oleh sebagian besar $(63,3 \%)$ bayi dengan rata-rata konsumsi 51,0\%. Makanan selingan yang sering dikonsumsi bayi usia 1224 bulan di Kelurahan Isola adalah biskuit hal ini terlihat bahwa 56,7\% bayi mengonsumsi biskuit dengan frekuensi 1x/hari dan rata-rata konsumsinya yaitu sebanyak 20,4 gram. Sedangkan jenis makanan seperti siomay, cilok, gehu dan basreng sebagian besar tidak pernah dikonsumsi oleh bayi.

Minuman jus buah dikonsumsi oleh $56,7 \%$ bayi usia $12-24$ bulan dengan frekuensi $3 \mathrm{x} / \mathrm{minggu}$ dan ratarata konsumsinya adalah 165,1 gram. Susu kotak dikonsumsi oleh $30 \%$ bai dengan frekuensi $1 \mathrm{x} /$ hari dan rata-rata konsumsinya yaitu 125,0 gram. Minuman kemasan seperti ale-ale, teh kemasan dan okky jelly drink sebagian besar tidak pernah dikonsumsi oleh bayi usia 12-24 bulan di Kelurahan Isola. 


\section{Tingkat Kecukupan Gizi Makanan Pendamping ASI (MP-ASI)}

Berdasarkan hasil penelitian bahwa kontribusi energi MP-ASI terhadap pemenuhan Angka Kecukupan Energi adalah sebanyak 58,9\% dengan rata-rata konsumsi 662 kkal. Konsumsi energi pada bayi usia 12-24 bulan berdasarkan asupan MPASI berkisar antara 125-1008 kkal $(662 \pm 152 \mathrm{kkal})$, hal ini selaras dengan penelitian Egayanti (2017, hlm.41) bahwa pada kelompok umur 12-23 bulan kontribusi pemenuhan energi dari MP-ASI sebagian besar dinyatakan kurang $(<80 \%)$ dari nilai AKG.

Rata-rata konsumsi protein bayi usia 12-24 bulan adalah 20,8 g/hari, dengan konsumsi protein berkisar antara 2-46 gram $(20,8 \pm 7,9$ gram $)$ sehingga kontribusi tingkat kecukupan gizi protein untuk bayi usia 12-24 bulan di Kelurahan Isola adalah 80,2\% dari angka kecukupan protein. Hasil penelitian Egayanti (2017, hlm.41) mengenai pemenuhan kebutuhan protein bayi usia 12-23 bulan sebagian besar dinyatakan melebihi (>120\%) dari total $\mathrm{AKG}$, hal tersebut berbeda dengan hasil penelitian ini yaitu $80,2 \%$ dari total AKG.

Kecukupan lemak pada bayi usia 12-24 bulan berdasarkan Angka Kecukupan Gizi 2014 adalah sebanyak 44 g/hari. Berdasarkan hasil penelitian, rata-rata konsumsi lemak pada bayi usia 12-24 bulan adalah 19,1 g/hari dengan konsumsi kisaran $2,0-37,0$ gram $(19,2 \pm 7,2$ gram $)$ sehingga kontribusi tingkat kecukupan lemak pada bayi usia 12-24 bulan sebesar 43,5\%.

Kecukupan karbohidrat untuk bayi usia 12-24 bulan menurut Angka Kecukupan Gizi 2014 adalah sebanyak 155 g/hari. Rata-rata konsumsi karbohidrat dari asupan MP-ASI pada bayi usia 12-24 bulan adalah 107,0 g/hari dengan kisaran konsumsi antara 19-273 gram $(107,0 \pm 41,4$ gram $)$, sehingga kontribusi tingkat kecukupan gizi karbohidrat terhadap pemenuhan AKG yaitu sekitar 69,1\%.

Kecukupan zat gizi kalsium pada bayi usia 12-24 bulan berdasarkan Angka Kecukupan Gizi 2014 sebanyak 650 mg/hari. Rata-rata konsumsi kalsium pada bayi usia 1224 bulan sebanyak 152,2 mg/hari. Konsumsi kalsium kisaran antara 27,0-708,0 mg/hari $(152,2 \pm 134,9$ gram) sehingga kontribusi tingkat kecukupan yang dihasilkan sekitar $23,4 \%$.

Fosfor sangat diperlukan unuk proses pertumbuhan tulang dan gigi pada bayi usia 12-24 bulan. Kecukupan fosfor berdasarkan Angka Kecukupan Gizi untuk usia 12-24 bulan yaitu $500 \mathrm{mg} /$ hari. Konsumsi fosfor pada bayi usia 12-24 bulan memiliki rata-rata konsumsi sebesar 178,3 mg/hari dengan kisaran konsumsi antara 27,0-555,0 mg/hari $(178,3 \pm 92,4 \mathrm{mg})$ dengan kontribusi tingkat kecukupan gizi sebanyak $35,7 \%$.

Kebutuhan zat besi bagi bayi usia 12-24 bulan sangat penting pemenuhannya. Kecukupan zat besi 
berdasarkan Angka Kecukupan Gizi adalah $8,0 \mathrm{mg} / \mathrm{hari}$. Rata-rata konsumsi zat besi pada bayi usia 1224 bulan adalah $5,3 \mathrm{mg} /$ hari dengan besaran konsumsi antara 1,0 - 22,0 $\mathrm{mg} /$ hari (5,3 \pm 4,8 $\mathrm{mg})$, sehingga kontribusi tingkat kecukupan zat gizi besi sekitar $66,4 \%$ dari total AKG zat besi.

Vitamin yang dibutuhkan oleh bayi usia 12-24 bulan diantaranya vitamin A, dengan kecukupan berdasarkan Angka Kecukupan Gizi 2014 sebanyak 400 RE/hari. Rata-rata konsumsi Vitamin A bayi usia 12-24 bulan adalah sebanyak 263,3 RE dengan konsumsi kisaran antara 2.01052 RE/hari (263,3 \pm 206,5 RE). Berdasarkan perhitungan tersebut maka pemenuhan vitamin A dari konsumsi MP-ASI bayi usia 12-24 bulan sekitar $65,8 \%$.

Kecukupan vitamin C berdasarkan AKG 2014 sebanyak 40 $\mathrm{mg}$ /hari. Rata-rata konsumsi vitamin $\mathrm{C}$ untuk bayi usia 12-24 bulan di Kelurahan Isola adalah sebesar 23,5 $\mathrm{mg} /$ hari dengan konsumsi antara 1,0 219,0 mg (23,5 \pm 33,8 mg) sehingga kecukupan vitamin $\mathrm{C}$ pada bayi usia 12-24 bulan terhadap pemenuhan AKG yaitu sekitar 58,7\%.

Tabel 2. Kontribusi Tingkat Kecukupan Gizi MP-ASI Terhadap AKG

\begin{tabular}{|c|c|c|c|}
\hline Zat Gizi & $\begin{array}{c}\mathrm{AK} \\
\mathrm{G}\end{array}$ & $\begin{array}{l}\text { Kontribus } \\
\text { i } \\
\text { Rata-Rata } \\
\text { Konsumsi }\end{array}$ & $\begin{array}{c}\text { Kontribusi } \\
\text { Tingkat } \\
\text { Kecukupa } \\
\mathrm{n} \\
\text { Zat Gizi } \\
(\%)\end{array}$ \\
\hline Energi & $\begin{array}{l}1125 \\
\text { kkal }\end{array}$ & $662 \mathrm{kkal}$ & 58,9 \\
\hline
\end{tabular}

\begin{tabular}{lccc} 
Protein & $26 \mathrm{~g}$ & $20,8 \mathrm{~g}$ & 80,2 \\
Lemak & $44 \mathrm{~g}$ & $19,1 \mathrm{~g}$ & 43,5 \\
Karbohidra & 155 & $107,0 \mathrm{~g}$ & 69,1 \\
$\mathrm{t}$ & $\mathrm{g}$ & & \\
Kalsium & 650 & $152,2 \mathrm{mg}$ & 23,4 \\
\multirow{2}{*}{ Fosfor } & 500 & & \\
& $\mathrm{mg}$ & $178,3 \mathrm{mg}$ & 35,7 \\
Besi & 8,0 & $5,3 \mathrm{mg}$ & 66,4 \\
\multirow{2}{*}{ Vitamin A } & 400 & $263,3 \mathrm{RE}$ & 65,8 \\
\multirow{2}{*}{ Vitamin C } & 40 & $23,5 \mathrm{mg}$ & 58,7 \\
\hline
\end{tabular}

Kontribusi zat gizi dari MP-ASI pada bayi usia 12-24 bulan di Kelurahan Isola seharusnya mendekati AKG yang telah ditetapkan, karena pada tahapan usia ini produksi ASI dan kualitas ASI sudah menurun sehingga pemenuhan kebutuhan gizi lebih banyak diperoleh dari konsumsi MP-ASI. Kontribusi zat gizi dari MPASI (tanpa asupan ASI dan susu formula) terhadap pemenuhan $\mathrm{AKG}$ pada bayi usia 12-24 bulan seperti kecukupan energi MP-ASI adalah sebanyak $58,9 \%$, kontribusi zat gizi protein sebesar $80,2 \%$, kontribusi zat gizi lemak sebanyak $43,5 \%$ dan kontribusi karbohidrat sebesar $69,1 \%$ dari AKG. Kontribusi tingkat kecukupan mineral MP-ASI terhadap pemenuhan AKG yaitu kalsium sebanyak 23,4\%, fosfor sebesar $35,7 \%$, dan zat besi memenuhi $66,4 \%$. Selanjutnya kontribusi vitamin terhadap AKG adalah vitamin A memenuhi $65,8 \%$ dan vitamin $\mathrm{C}$ memenuhi sebesar 58,7\% dari AKG.

\section{KESIMPULAN}

Berdasarkan hasil penelitian mengenai "Pola Konsumsi Makanan Pendamping ASI (MP-ASI) pada Bayi Usia 12-24 Bulan" dapat disimpulkan bahwa jenis makanan pendamping ASI (MP-ASI) pada bayi usia 12-24 bulan sebagian kecil $(18,3 \%)$ bayi 
masih diberikan makanan lunak dan 5\% masih mengonsumsi makanan berbentuk lumat namun sebagian besar $(76,7 \%)$ bayi sudah mengonsumsi jenis makanan sesuai dengan anjuran yaitu jenis makanan padat seperti nasi dan lauk pauk. Frekuensi pemberian makanan pendamping ASI sudah sesuai dengan anjuran Kemenkes 2014 yaitu frekuensi pemberian makan pada bayi usia 12-24 bulan lebih dari setengahnya $(65 \%)$ mengonsumsi makanan utama dengan frekuensi 3-4 kali/hari dan lebih dari setengahnya $(68,3 \%)$ mengonsumsi makanan selingan dengan frekuensi $2 x /$ hari. Kontribusi energi dari MP-ASI terhadap pemenuhan AKG yaitu sekitar 58,9\%, zat gizi protein memiliki tingkat kecukupan sebesar $80,2 \%$. kontribusi zat gizi lemak sebanyak $43,5 \%$ dan kontribusi karbohidrat sebesar $69,1 \%$ dari total AKG. Tingkat kecukupan mineral MP-ASI terhadap pemenuhan AKG yaitu kalsium sebanyak $23,4 \%$, fosfor sebesar $35,7 \%$, dan zat besi memenuhi $66,4 \%$. Selanjutnya kontribusi vitamin terhadap AKG adalah vitamin A memenuhi $65,8 \%$ dan vitamin $\mathrm{C}$ memenuhi sebesar $58,7 \%$.

\section{REFERENSI}

Allen dan Lynn R Marotz. (2010). Profil Perkembangan Anak : Prakelahiran Hingga Usia 12 Tahun. Jakarta: Indeks.

Egayanti, Yusra. (2017). Profil Konsumsi dan Kontribusi Makanan Pendamping Air Susu Ibu (Mp-Asi) dalam Pemenuhan Gizi Bayi dan Anak Indonesia. (Tesis). Sekolah pascasarjana, Institut Pertanian Bogor, Bogor.
Kementerian Kesehatan. (2014). Pedoman Gizi Seimbang. Jakarta: Kemenkes.

Kementerian Kesehatan . (2010). Telur Sumber Makanan Bergizi. Jakarta : Kemenkes dan Kementerian Peternakan RI.

Mufida, dkk. (2015). Prinsip Dasar Makanan Pendamping Air Susu Ibu (MP-ASI) Untuk Bayi 6 24 Bulan : Jurnal Pangan dan Agroindustri Vol. 3 No 4 p.1646-1651, September 2015, Universitas Brawijaya Malang.

Nurhayati, Ai. (2000). Faktor-Faktor yang Berpengaruh Terhadap Status Gizi Anak Usia 6-24 bulan di Kecamatan Bandung Kulon Kotamadya Bandung. (Tesis). Program Pascasarjana, Institut Pertanian Bogor, Bogor.

Palandeng dkk. (2016). Karakteristik Fisiko-Kimia dan Sensori Sosis Ayam Petelur Afkir yang Difortifikasi dengan Pasta dari Wortel. Program Studi Ilmu Pangan, Pascasarjana, Universitas Sam Ratulangi. J. Ilmu dan Teknologi Pangan, Vol. 4 No. 2 Th. 2016.

Perdana dan Hardinsyah. (2013). Analisis Jenis, Jumlah, dan Mutu Gizi Konsumsi Sarapan Anak Indonesia, Jurnal Gizi dan Pangan, Maret 2013, 8(1): 39-46, ISSN 1978 - 1059. Departemen Gizi Masyarakat: Institut Pertanian Bogor, Bogor.

Riduwan. (2010). Dasar-Dasar Statistika. Bandung: CV Alfabeta.

Sudjana. (2010). Metoda Statistika. Bandung: PT Tarsito.

Sumartini, dkk. (2015). Studi Paparan Pemanis Buatan Aspartam pda Minuman Ringan yang Dikonsumsi Siswa/I SMP 
Negeri 1 Cimaung Kabupten Bandung dengan Menggunakan Metode Food Frequency Questionnaire. Prodi Farmasi FMIPA< Universitas Islam Bandung (UNISBA).

Unicef. (2012). Paket Konseling: Pemberian Makan Bayi dan Anak.
Wahyuningsih, Tri. (2017). Sifat Kimia , Kekerasan Dan Organoleptik Stick Tahu Dengan Substitusi Tepung Sukun (Artocarpusaltilis). (Tesis). Universitas Muhammadiyah Semarang. 